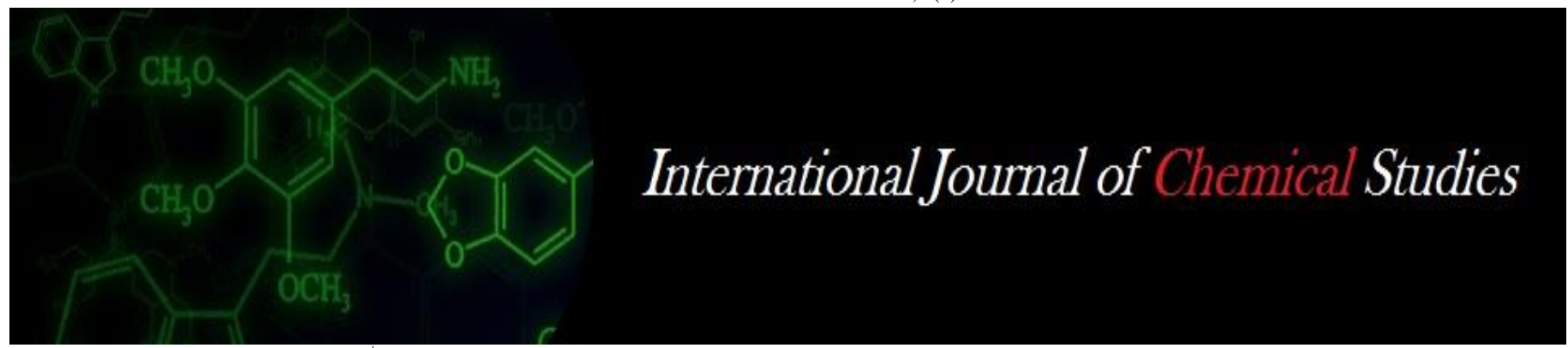

P-ISSN: 2349-8528

E-ISSN: 2321-4902

www.chemijournal.com

IJCS 2020; 8(5): 2707-2712

(C) 2020 IJCS

Received: 12-06-2020

Accepted: 19-08-2020

Amit Bijlwan

Department of Agrometeorology,

G.B Pant University of

Agriculture and Technology,

Pantnagar, U.S Nagar,

Uttarakhand, India

\section{Ravi Kiran}

Associate Professor, Department of Agrometeorology, G.B Pant

University of Agriculture and

Technology, Pantnagar, U.S

Nagar, Uttarakhand, India

\section{AS Nain}

Professor, Department of Agrometeorology, G.B Pant

University of Agriculture and

Technology, Pantnagar, U.S

Nagar, Uttarakhand, India

\section{Shweta Pokhariyal}

Department of Agrometeorology,

G.B Pant University of

Agriculture and Technology,

Pantnagar, U.S Nagar,

Uttarakhand, India
Corresponding Author:

Amit Bijlwan

Department of Agrometeorology,

G.B Pant University of

Agriculture and Technology,

Pantnagar, U.S Nagar,

Uttarakhand, India

\section{Effect of planting date and mulching on maize sugar-75 (Zea mays L.) yield in Tarai region of Uttarakhand}

\author{
Amit Bijlwan, Ravi Kiran, AS Nain and Shweta Pokhariyal
}

DOI: https://doi.org/10.22271/chemi.2020.v8.i5ak.10727

\begin{abstract}
The study was conducted at Norman E. Borlaug Crop Research Centre of Govind Ballabh Pant University of Agriculture and Technology, Pantnagar, U.S Nagar (Uttarakhand) during Kharif seasons of 2018. Three planting date viz. $11^{\text {th }}$ July, $23^{\text {rd }}$ July and $21^{\text {st }}$ August 2018 and three types of mulching material with one control treatment viz. Dhaincha mulch, Green weed mulch and Plastic mulch was studied during the experimental period. Hybrid maize variety Maize Sugar 75 was used for the study. The experiment was laid out in 2- factorial Randomized design with three number of replication having net plot size $5 \mathrm{~m} \times 3 \mathrm{~m}$. The various ancillary observations on the growth were periodically recorded along with post-harvest studies to evaluate the treatment effects. Green cob yield and grain yield was maximum for $11^{\text {th }}$ July sowing and lowest for $21^{\text {st }}$ August sown maize sugar 75 .
\end{abstract}

Keywords: Maize sugar 75, sweet corn, planting date, organic \& inorganic mulch

\section{Introduction}

Corn (Zea mays L.) is grown almost all over the world in different agro-climatic conditions and in different seasons and it is one of the most important cereals for both human and animal consumption. Sweet corn is one of the most popular vegetables in the USA, Europe and other developed countries of the world. It is a very delicious and rich source of energy, vitamin $\mathrm{C}$ and A.Corn is best grown in an environment that provides warm weather and long sunny days. During the day, maize is grown between 18-27 degree Celsius and during the night at 14 degree Celsius temperature is considered good for corn growth. Corn is very sensitive to frost; therefore, its cultivation is limited in temperate latitudes (Maddonni, G. A. 2012) ${ }^{[1]}$. During flowering, high temperature and low humidity damage the leaves weakens pollen and interfere with proper pollination, resulting in poor grain formations. $50-70 \mathrm{~cm}$ well distributed rain is suitable for proper growth and development.

Sweet corn can be harvested between 80 and 90 days after sowing. It is harvested 35 to 45 days prior as compared to normal corn. Its cobs has also good market potential. The weather should not be too cold or there will be slow germination, poor growth, wearing a few small ears and even death if it is damaged by frost. Green cobs are harvested after 18-20 days of pollination during Kharif but the duration may varies season to season. At the harvest time the moisture is generally $70 \%$ in the grain and sugar content varies from 11 to more than $20 \%$.

Mulching is one of the most important moisture conservation practice in rain-fed agriculture among various mechanical and agronomic measures that have been reported to reduce the soil erosion and increase in-situ soil moisture storage. To improve the efficiency and effectiveness of water use, the most convenient agronomic management practice are cropping system, mulching and irrigation scheduling in the case of maize production. Mulching of crop residues is an encouraging management option for decreasing soil water evaporation, with other benefits at much lower costs and improved soil health. Residue mulch on the soil surface reduces evaporation, regulates soil temperature and increases soil porosity in long term practices. 


\section{Materials and Methods}

To see the effect of different types of mulches and sowing dates on crop growth, the field experiments was conducted at plot number C4 of Norman E. Borlaug Crop Research Centre of Govind Ballabh Pant University of Agriculture and Technology, Pantnagar, U.S Nagar (Uttarakhand) during Kharif seasons of 2018. The experimental site is situated at latitude of $29.02^{\circ} \mathrm{N}, 79.25^{\circ} \mathrm{E}$ longitude and at an altitude of $238 \mathrm{~m}$ above the mean sea level. The average annual rainfall is $1405 \mathrm{~mm}$. May is the hottest month of the year in the region and temperature generally rises up to $45.5^{\circ} \mathrm{C}$. However, minimum temperature can be low as $1.5^{\circ} \mathrm{C}$ in the month of January. Generally, the monsoon sets in around $3^{\text {rd }}$ week of June and lasts up to end of the September.

\subsection{Treatment details}

The experiment was conducted with following treatments. Three planting date viz. $11^{\text {th }}$ July, $23^{\text {rd }}$ July and $21^{\text {st }}$ Augest 2018 and four types of mulching material. Mulching treatment includes control treatment (M1), Dhaincha (Sesbania aculeata) (M2), green weed (M3) and black polythene mulch (M4).

Dhaincha which was used as mulch was collected from the nearby fields. In case of green weed mulch, weeds which was collected during weeding of crop at different stages was used as mulch.

\section{Crop variety used- Maize sugar 75}
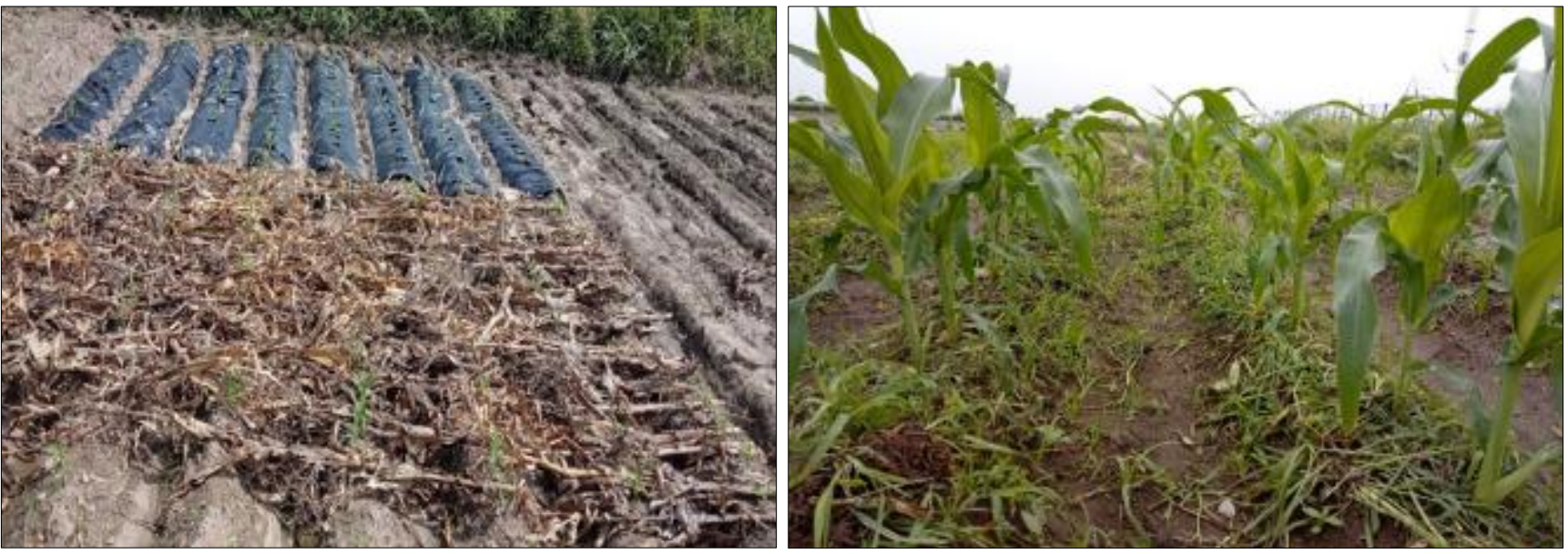

Fig 1: Plastic, Dhaincha and green weed mulch treatment

\subsection{Fertilizer application}

During the experiment recommended dose of nitrogen, phosphorus and potassium were applied with the rate of 150$60-40 \mathrm{~kg}$ per hectare respectively. Zinc was also applied at the rate of $25 \mathrm{~kg}$ per hectare at the time of sowing. Phosphors and Potassium was applied as a whole at the time of sowing. Nitrogen is applied $20 \%$ as a basal dose at the time of sowing. Remaining nitrogen was applied as splitting at eight leaf stage, tasseling, and grain filling stage at the rate of $25 \%$, $30 \%$, and $25 \%$ respectively.

Under Plastic film mulch all the fertilizers were applied in half quantity to avoid injury by applying it in nearness to plant root zone.

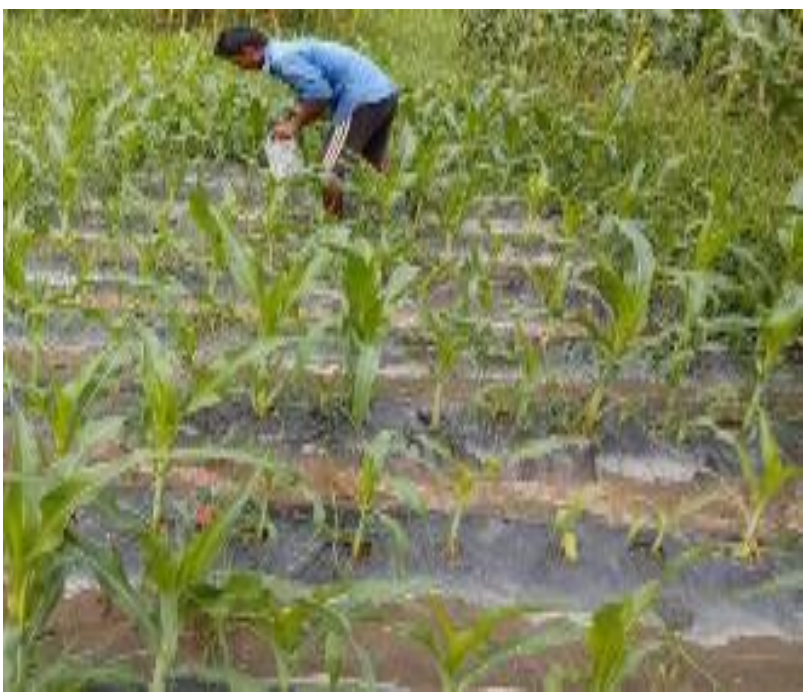

Fig 2: Application of fertilizer in plastic film mulch

\section{Result and discussion}

\subsection{Effect on plant growth parameter}

All the plant growth parameter like Plant height, Leaf Area Index and Biomass accumulation was significantly affected by different date of sowing and mulching treatment (Table 1). When compared to green weed mulch, dhaincha mulch and control treatment the plant height under plastic film mulch was $5.05,5.95$ and $0.74 \%$ higher respectively for $1^{\text {st }}$ date of sowing. For second date of sowing plant height under plastic film mulch was higher by $22.18,32.01$ and $14.08 \%$ respectively and for third date of sowing the plant height under plastic film mulch was higher by $10.12,0.27$ and $7.79 \%$. The higher plant height in polythene mulched plots might be due to excellent weed control, along with initial soil moisture and temperature. (Mahajan et al., 2007) ${ }^{[2]}$. The lower plant height in dhaincha mulch treatment could be the result of competition between sweet corn and weeds for the environmental parameter such as light, water, and space which reduces photosynthesis and production (Kahangi et al., 2014) ${ }^{[3]}$.

Leaf area index under plastic film mulch was higher by 3.82 , 11.26 and $2.01 \%$ respectively for first date of sowing when compared to green weed mulch, dhaincha mulch and control treatment. For second date of sowing leaf area index under plastic film mulch was higher by $19.46,28.34$ and $16.64 \%$ respectively and for third date of sowing leaf area index under plastic film mulch was higher by $14.60,6.62$ and $9.31 \%$ respectively. Higher leaf area index was observed for plastic film mulch treatment as a comparison to dhaincha mulch because of the lower density of weed presence, thus providing favorable conditions which also accelerated vegetative growth in particularly under polythene mulch treatment (Gul et al., 2009) ${ }^{[4]}$. 
Dry matter accumulation under plastic film mulch was higher by $6.63,11.45$ and $5.82 \%$ respectively when compared to green weed mulch, dhaincha mulch and control treatment for first date of sowing. For second date of sowing the average dry matter accumulation under plastic film mulch was higher by $16.82,24.20$ and $5.41 \%$ respectively and for third date of sowing it was higher by $20.65,4.68$ and $6.52 \%$ respectively. The result is in accordance with $\mathrm{Xu}$ et al. (2015) ${ }^{[5]}$ who recorded a greater accumulation of dry matter by plastic film mulching at an early stage of growth such as the pre-silking stage.

Table 1: Effect of planting date and mulching on plant height, LAI and dry matter accumulation

\begin{tabular}{|c|c|c|c|c|}
\hline \multicolumn{5}{|c|}{ Plant height at harvesting (cm) } \\
\hline & M1 & M2 & M3 & M4 \\
\hline $1^{\text {st }}$ DOS & 222.33 & 210.67 & 212.67 & 224.00 \\
\hline $2^{\text {nd }}$ DOS & 230.00 & 182.00 & 208.30 & 267.70 \\
\hline $3^{\text {rd }}$ DOS & 224.67 & 243.00 & 219.00 & 243.67 \\
\hline \multicolumn{5}{|c|}{ Leaf area index at harvesting } \\
\hline $1^{\text {st }}$ DOS & 4.88 & 4.41 & 4.79 & 4.97 \\
\hline $2^{\text {nd }}$ DOS & 4.91 & 4.38 & 4.65 & 5.63 \\
\hline $3^{\text {rd }}$ DOS & 4.51 & 4.12 & 4.38 & 4.83 \\
\hline \multicolumn{5}{|c|}{ Dry matter accumulation at harvesting (gm.) } \\
\hline $1^{\text {st }}$ DOS & 210.41 & 197.79 & 208.56 & 223.39 \\
\hline $2^{\text {nd }}$ DOS & 236.50 & 189.50 & 207.97 & 250.04 \\
\hline $3^{\text {rd }}$ DOS & 198.57 & 168.55 & 202.47 & 212.43 \\
\hline
\end{tabular}

3.2 Effect of planting date, mulching type on Developmental stages

3.2.1 Days to emergence

The number of days taken for 50 percent germination did not vary significantly either due to the date of sowing and/or due to mulches, in maize. The interaction effect of the above treatments was also found non-significant on days to 50 percent germination. The crop nearly took 5 days to attain 50 percent germination (Table 2).

\subsubsection{0\% Tasseling}

Days taken to reach 50 percent tasseling were significantly more (57) in the second date of sowing as compared to the first and third date of sowing. Significantly, the lowest days to reach tasseling stage were recorded for the late sown maize i.e. 44.83 days. The minimum days required for $50 \%$ tasseling was 49.11 days under black polythene mulching (Table 2).

The results are in agreement with Lenka (1998) [6] who concluded that delay sowing in Kharif and summer season reduced days to tasseling. Early planting tends to place the tasseling and silking period ahead of the greatest risk of moisture stress and drought damage (Sangoi 1993) ${ }^{[7]}$. The early tasseling in plastic mulches could be attributed to an increase in soil moisture and temperature, which may have promoted early tasseling. These findings for the plastic mulches are in agreement with the results of Rifin (1988) ${ }^{[8]}$ who reported that mulches induced early tasseling and silking in maize. These results are also in line with the work of Yonghe (1994) ${ }^{[9]}$ who reported that under different cropping systems, plastic mulch significantly raised the soil temperature, kept soil water content stable and enhanced microbial activity and as a result crops grew faster.

\subsubsection{0\% Silking}

The second sown sweet corn was found to take maximum
(58.42) days for attaining silking stage followed by the first date of sowing (51.58). Significantly, the lowest days to reach tasseling stage were recorded for the late sown maize i.e. 46.08 days. Days taken to 50 percent tasseling were significantly more in dhaincha mulch compared to other mulch treatment. Tasseling was 2 days earlier under plastic film mulch compared to dhaincha mulch treatment. Days required for $50 \%$ tasseling increased with other mulch when compared to plastic film mulch (Table 2).

The lowest days taken for silking in the late sown crop may probably be due to delayed planting of the maize crop. The results are consistent with the studies of various research workers worldwide Mosavi et al., (2012) ${ }^{[10]}$; Ali et al., (2014) ${ }^{[11]}$ and Ahsan et al., (2011) ${ }^{[12]}$. The early silking in plastic mulches might be attributed to the effects of mulch material in increasing soil temperature and moisture that induced early flowering and maturity (Lalitha et al., 2010) ${ }^{[13]}$.

Table 2: Effect of planting date, mulching type on Developmental stages for Kharif sweet corn 2018

\begin{tabular}{|c|c|c|c|}
\hline Treatment & Germination (50\%) & Tasseling (50\%) & Silking (50\%) \\
\hline \multicolumn{4}{|c|}{ Effect of date of sowing } \\
\hline D1 & 4.00 & 49.75 & 51.58 \\
\hline D2 & 5.00 & 57.00 & 58.42 \\
\hline D3 & 5.00 & 44.83 & 46.08 \\
\hline SE(m) & 0.41 & 0.48 & 0.32 \\
\hline C.D. (at 5\%) & NS & 1.42 & 0.93 \\
\hline \multicolumn{5}{|c|}{ Effect of mulching } \\
\hline M1 & 4.67 & 48.89 & 52.22 \\
\hline M2 & 4.67 & 51.33 & 52.55 \\
\hline M3 & 4.67 & 50.77 & 52.55 \\
\hline M4 & 4.67 & 49.11 & 50.77 \\
\hline SE(m) & 0.47 & 0.56 & 0.36 \\
\hline C.D. (at 5\%) & NS & 1.64 & 1.08 \\
\hline
\end{tabular}

3.3 Effect of planting date, mulching type on Yield and yield components

\subsubsection{Number of grain rows $\operatorname{cob}^{-1}$}

Total Number of grain rows $\mathrm{cob}^{-1}$ was maximum at first date of sowing followed by second and third date of sowing. The number of grains rows per cob was significantly higher in plastic film mulch (14.76) and dhaincha mulch (14.13) as compared to green weed mulch (13.53) and control (12.91) (Table 3).

\subsubsection{Cob length $(\mathrm{cm})$}

Highest cob length was observed with first date sown crop and lowest for late i.e. third date sown crop. Cobs are shorter under plastic film mulch. As the grain filling was not up to the top of cob, it resulted in shorter cobs (Table 3).

A decrease in cob length was noticed with delay in sowing and conformed to the findings of Ibrahim et al. (2013) ${ }^{[14]}$ who reported that delayed sowing of maize from optimum sowing date would result in shorter cobs.

\subsubsection{Number of grains/row}

A decrease in the number of grains per row was noticed with a delay in sowing. Under different mulching treatment plastic film mulch showed low gain filling rate and number of grains in a row was also reduced. It was due the soil cover by plastic film mulch and hence over the time it reduces the soil moisture and availability of nitrogen for gain filling (Table 3). 
Table 3: Effect of planting date, mulching on Cob length, No. of green cob per plant, No. of grains row per cob and No. of grains per row for Kharif sweet corn 2018

\begin{tabular}{|c|c|c|c|c|}
\hline Treatment & Cob length (cm) & No. of cobs/plant & Grains row/cob & No. of grains/row \\
\hline \multicolumn{5}{|c|}{ Effect of date of sowing } \\
\hline D1 & 14.94 & 1.09 & 13.80 & 31.64 \\
\hline D2 & 13.72 & 1.05 & 13.43 & 29.67 \\
\hline D3 & 12.86 & 1.03 & 13.27 & 29.55 \\
\hline SE(m) & 1.33 & 0.08 & 0.27 & 0.95 \\
\hline C.D. (at 5\%) & NS & NS & NS & NS \\
\hline \multicolumn{5}{|l|}{ Effect of mulching } \\
\hline M1 & 13.01 & 1.06 & 12.91 & 30.00 \\
\hline M2 & 13.18 & 1.03 & 14.13 & 30.64 \\
\hline M3 & 16.40 & 1.09 & 13.53 & 31.32 \\
\hline M4 & 12.76 & 0.99 & 14.76 & 29.18 \\
\hline SE(m) & 1.54 & 0.03 & 0.31 & 1.10 \\
\hline C.D. (at 5\%) & NS & NS & 0.90 & NS \\
\hline
\end{tabular}

\subsubsection{Green cob weight $\left(10^{-2} \mathrm{~kg}\right)$}

The highest cob weight was found in the first date of sowing $\left(30.8910^{-2} \mathrm{~kg}\right.$ ) followed by second $\left(26.0510^{-2} \mathrm{~kg}\right)$ and the third date of sowing $\left(23.0410^{-2} \mathrm{~kg}\right)$ (Table 4). The significant reduction in cob weight with different sowing dates could be due to the decreased incident solar radiation in the season which finally reduced both cob length and cob weight through a reduction in biomass production (Maddonni et al., 1998) ${ }^{[15]}$.

\subsubsection{Green cob yield (t/ha)}

The maximum green cob yield was with the first date of sowing (22.72 t/ha) followed by second (17.28 t/ha) and third (16.80 t/ha) date of sowing for the Kharif sweet corn. The effect of different mulching material on the green cob yield of sweet corn was not significant and the green cob yield was almost equal to each other under all the mulching treatment under Tarai region of pantnagar (Table 4).

The maximum yield in the first date of maize sown crop has taken the advantage of optimum temperature, rainfall and sunlight during early stages of plant development and thereby avoided adverse situations during its life cycle whereas, the minimum yield for the last date of sowing may be attributed to high-stress conditions of increased maximum and minimum temperature coupled with sunshine duration. The findings are in the tune with Girijesh et al. (2011) ${ }^{[16]}$; Singh and Hadda, (2014) ${ }^{[17]}$.

\subsubsection{Grain yield $\left(10^{2} \mathrm{~kg} / \mathrm{ha}\right)$}

The maximum grain yield $(76.20 \mathrm{~kg} / \mathrm{ha})$ obtained with the first date of sowing and was significantly higher when compared to second $(69.60 \mathrm{~kg} / \mathrm{ha})$ and third date of sowing $(64 \mathrm{~kg} / \mathrm{ha})$. The seed yield is the function of the combined effect of all the yield components under the influence of a particular set of environmental conditions. The delay in planting gradually decreased the yield because of a decrease in temperature at the end of the season.

Higher grain yield was recorded with dhaincha mulch $(75.80$ $\mathrm{kg} / \mathrm{ha}$ ) when compared with green weed mulch $(68.30 \mathrm{~kg} / \mathrm{ha})$, control treatment $(68.30 \mathrm{~kg} / \mathrm{ha})$ and plastic film mulch $(67.50$ $\mathrm{kg} / \mathrm{ha}$ ). Grain yield under dhaincha mulch treatment was higher by $9.88 \%, 11 \%$ and $9.88 \%$ for green weed mulch, control treatment, and plastic film mulch respectively (Table 4). Reduced grain yield under plastic film mulch was the combined result of short cob length, lowest number of gains per row and low gain filling rate.

Schopher et al. (1982) [18] reported that increasing light interception through early planting date has increased maize yields. In a study carried out by Johnson and Mulvaney (1980) ${ }^{[19]}$, higher grain moisture and 5\% yield loss was generally recorded at harvest in the case of late planted maize hybrids.

Table 4: Effect of planting date, mulching type on Green cob weight $\left(10^{-2} \mathrm{~kg}\right)$, Test weight $(\mathrm{g})$, Green cob yield ( $\left.\mathrm{t} / \mathrm{ha}\right)$ and Grain yield $\left(10^{2}\right.$ $\mathrm{kg} / \mathrm{ha}$ ) for Kharif sweet corn 2018

\begin{tabular}{|c|c|c|c|c|}
\hline Treatment & Green cob weight $\left(10^{-2} \mathrm{~kg}\right)$ & Test weight (g) & Green cob yield (t/ha) & Grain yield $\left(10^{2} \mathrm{~kg} / \mathrm{ha}\right)$ \\
\hline \multicolumn{5}{|c|}{ Effect of date of sowing } \\
\hline D1 & 30.89 & 22.19 & 22.72 & 76.20 \\
\hline D2 & 26.05 & 20.95 & 17.28 & 69.60 \\
\hline D3 & 23.04 & 20.83 & 16.80 & 64.00 \\
\hline $\mathrm{SE}(\mathrm{m})$ & 1.12 & 0.22 & 0.26 & 1.10 \\
\hline C.D. (at 5\%) & 3.79 & 0.66 & 0.78 & 2.20 \\
\hline \multicolumn{5}{|c|}{ Effect of mulching } \\
\hline M1 & 27.22 & 21.66 & 19.04 & 68.30 \\
\hline M2 & 26.06 & 21.46 & 19.24 & 75.80 \\
\hline M3 & 24.58 & 21.22 & 18.17 & 68.30 \\
\hline M4 & 28.96 & 20.94 & 19.28 & 67.50 \\
\hline $\mathrm{SE}(\mathrm{m})$ & 1.40 & 0.26 & 0.31 & 0.80 \\
\hline C.D. (at 5\%) & NS & NS & NS & 2.50 \\
\hline
\end{tabular}

\section{Reasons for low grain yield under plastic film mulch}

Plants under polythene mulch initially grow faster due to the availability of the initial soil moisture and nutrient but when the plant goes through vegetative and grain filling stages the availability of soil moisture and nitrogen fertilizer is in limited amount and hence it results in lower grain filling in sweet corn crop under polythene mulch treatment.

Under polythene film mulch the grain yield was not significantly higher when compared with the other treatment of the study. There were mainly two reasons for it:- 
- The area for the application of fertilizers under plastic film mulch was lower and thus half of the amount of fertilizer were applied at different growth stages. This was done to prevent injury due of higher amount of urea to be applied near the plant root zone. This results in low availability of nitrogen to the plant at the time of grain filling stage and thus ultimately affects the final grain yield.

- Another reason for the lower grain yield was the lower availability of water in the plastic film mulch treatment at the later stages of plant growth. At the time of irrigation, most of the water remained on the polythene mulch and thus water didn't penetrate the soil. It resulted in the lower soil moisture under the polythene mulch.

Under the dhanincha mulch treatment the crop growth parameter like plant height, leaf area index, dry matter accumulation was lower as compare to the other treatment during the experimental period. Application of dhanicha as a mulch is not enough to suppress the weed population so weed accumulation was very high during the period of crop growth. High accumulation of weed resulted to competition with maize crop and hence corn plants are shorter in height and low in accumulation of biomass.

As dhaincha act as a green manuring in field so the organic matter content of soil can be increased by green manuring with dhaincha (Sesbania rostrate), which contains about $1.25 \% \mathrm{~N}$ (Hossain et al., 1990) ${ }^{[20]}$ and supplies $200 \mathrm{~kg} \mathrm{~N} / \mathrm{ha}$ when incorporated 50 days after sowing (Rinaudo et al., 1983) [21]. Furthermore, green manuring together with nitrogen fertilizer helps release nutrients more slowly during the period of crop growth (Singh et al., 1990) ${ }^{[22]}$.

The slow release of nitrogen in dhaincha mulch and supply of nitrogen in later growth stage enhances the grain filling rate and it resulted in more grains in sweet corn. It finally result in more grain yield.

\section{Conclusion}

All the crop growth parameter like plant height, leaf area index, biomass accumulation was higher under plastic film mulch as compare to other mulching material. As optimum plating date provides better growing condition for plat growth. Hence $11^{1 \text { th }}$ July sown crop results in higher green cob yield and grain yield as compare to $23^{\text {rd }}$ July and $21^{\text {st }}$ August sown crop. As all plant growth parameters are higher for plastic film mulch but it is not same for grain yield. Due to above said reason grain yield was reduced for plastic film mulch and higher for dhaincha mulch treatment. Organic mulches are efficient for moisture conservation and also to increase soil fertility in long turn.

\section{References}

1. Maddonni GA. Analysis of the climatic constraints to maize production in the current agricultural region of Argentina-a probabilistic approach. Theoretical and applied climatology 2012;107(3-4):325-345.

2. Mahajan G, Rakesh S, Kumar A, Singh KG. Effect of plastic mulch on economizing irrigation water and weed control in baby corn sown by different methods. African Journal of Agricultural Research 2007;2(1):19-26.

3. Kahangi HK, Rajablarijani HR, Nasri M. Effect of mung bean living mulch, plastic mulch and herbicides on for age maize yield and weed control. International Journal of Agriculture and Crop Sciences 2014;7(14):1452.
4. Gul B, Marwat MB, Hassan G, Khan A, Hashim S, Khan IA. Impact of tillage, plant population and mulches on biological yield of maize. Pakistan Journal of Botany 2009;41:2243-2249.

5. Xu J, Li C, Liu H, Zhou P, Tao Z, Wang $\mathrm{P}$ et al. The effects of plastic film mulching on maize growth and water use in dry and rainy years in Northeast China. PLOS one 2015;10(5):e0125781.

6. Lenka D, Mohapatra PK, Naik P. Effect of plastic mulching on yield and water use efficiency in maize. Annals of Agricultural Research 1998;19(2):210-211.

7. Sangoi L. Suitability of the fields of lages (SC) for corn production in different growing seasons. Brazilian Agricultural Research 1993;28:51-63.

8. Rifin A. Growth and yield of maize under various mulching, nitrogen application and soil moisture regimes. Dissertation of A. Rifin submitted to the Philippines Univ, Los Banos, College, Laguna (Philippines). Agricultural Water Management 1988;60:87-97.

9. Yonghe Z. Study on the impact of plastic mulch on selected crop agroecosystems in Yunna Province, People's Republic of China. Philippines Univ., Los Banos, College, Laguna (Philippines). University Library, University of the Philippines at Los Baños, Benguet State University, La Trinidad, Benguet 2601, Philippines 1994.

10. Mosavi SG, Seghatoleslami MJ, Ali M. Effect of planting date and plant density on morphological traits, LAI and forage corn (Sc. 370) yield in second cultivation. International Research Journal of Applied and Basic Sciences 2012;3:57-63.

11. Ali Q, Ali A, Waseem M, Muzaffar A, Ahmad S, Ali S, et al. Correlation analysis for morpho-physiological traits of maize (Zea mays L.). Life Science Journal 2014;11:913.

12. Ahsan M, Farooq A, Khaliq I, Ali Q, Aslam M, Kashif M. Inheritance of various yield contributing traits in Maize (Zea Mays L.) at low moisture condition. African Journal of Agricultural Research 2011;8:413-420.

13. Lalitha $M$, Kasthuri Thilagam V, Balakrishnan N, Mansour M. Effect of plastic mulch on soil properties and crop growth-a review. Agricultural Reviews 2010, 31(2).

14. Ibrahim HA, El-Behairy UA, El-Sawi Lashine ZA, ELDesuki M, Bakry OM, El-Shorbagy. Effect of sowing date and potassium fertilizer application on growth, yield and quality of sweet corn. Journal of Applied Sciences Research 2013;9(8):5126-5135.

15. Maddonni GA, Otegui ME, Bonhomme R. Grain yield components in maize. II. Post silking growth and kernel weight. Field Crops Research 1998;56:257-264.

16. Girijesh GK, Swamy KAS, Sridhara S, Kumar MD, Vageesh TS, Nataraju SP. Heat use efficiency and heliothermal units for maize genotypes as influenced by dates of sowing under southern transitional zone of Karnataka State. International journal for science and nature 2011;2(3):529-533.

17. Singh J, Hadda MS. Phenology and thermal indices of maize (Zea mays L.) influenced by subsoil compaction and nitrogen fertilization under semi-arid irrigated conditions. Journal of Applied and Natural Science 2014;6(2):349-355.

18. Schopher JB, Johnson RR, Lambert RJ. Maize yield response to increased assimilate supply. Crop Science 1982;22:1184-1189. 
19. Johnson RR, Mulvaney DL. Development of model for use maize replant decisions. Agronomy Journal 1980;50:459-464.

20. Hossain SMA, Bhuita MSU, Alam ABMM. Notes on vegetative propagation of Sesbania rostrate. Bangladesh Journal of Agricultural Sciences 1990;17:163-167.

21. Rinaudo G, Dreyfus B, Dommergues YR. Sesbania rostrata green manure and the nitrogen content of rice crop and soil. Soil Biology and Biochemistry 1983;15:111-113.

22. Singh NT, Mongia AD. Effect of mulching and phosphorus application on grain yield and profile waterdepletion pattern of maize (Zea mays L.), blackgram (Phaseolus mungo) and sesame (Sesamum indicum) in a tropical soil. Indian Journal of Agricultural Sciences 1990;59(8):503-505. 